\title{
Land Tenure and Conflict Resolution: A Game Theoretic Approach in the Narok District in Kenya
}

Hans M Amman and Anantha Kumar Duraiappah

Working Paper No 37

May 2001 


\section{Authors}

Hans M. Amman is Dean of Technology Management at the Technische Universiteit Eindhoven. Anantha Kumar Duraiappah, formerly of the Institute for Environmental Studies (IVM), is currently Director and Senior Economist of the Economic Policy Strategic Objective section at the International Institute for Sustainable Development.

They can be contacted at:

Prof. Dr Hans M. Amman

Technische Universiteit Eindhoven

Den Dolech 2

Tema 1.31

P.O. Box 513

$5600 \mathrm{MB}$ Eindhoven, The Netherlands

Telephone +3140247 3540/2635

Fax +31 402468526

e-mail: h.m.amman@tm.tue.nl

Dr Anantha Kumar Duraiappah

International Institute for Sustainable Development

161 Portage Avenue East, 6th Floor

Winnipeg, Manitoba, Canada

R3B OY4

Telephone: 1 (204) 958-7700

Fax: 1 (204) 958-7710

Email:akduraiappah@iisd.ca 
The programme of Collaborative Research in the Economics of Environment and Development (CREED) was established in 1993 as a joint initiative of the International Institute for Environment and Development (IIED), London, and the Institute for Environmental Studies (IVM), Amsterdam. The Secretariat for CREED is based at IIED in London. A Steering Committee is responsible for overall management and coordination of the CREED Programme.

\section{Environmental Economics Programme, IIED}

IIED is an independent, non-profit organisation which seeks to promote sustainable patterns of world development through research, training, policy studies, consensus building and public information. The Environmental Economics Programme is one of seven major programmes of IIED; it conducts economic research and policy analysis for improved management of natural resources and sustainable economic growth in the South.

Environmental Economics Programme

IIED, 3 Endsleigh Street

London WC1H ODD, UK

Tel +44 (0)20 7388 2117; Fax +44 (0)20 73882826

e-mail: frances.reynolds@iied.org

\section{Institute for Environmental Studies, (IVM)}

IVM is a non-profit research institute, based at Vrije Universiteit, Amsterdam. The Institute's primary objective is to carry out multi- and interdisciplinary research on environmental issues, based on crossfertilisation of monodisciplinary sciences. Environment and the Third World is one of eight major IVM research programmes.

IVM, Vrije Universiteit

De Boelelaan 1115

1081 HV Amsterdam

The Netherlands

Tel: +31 20444 9555; Fax: +31204449553

e-mail:secr@ivm.vu.nl

\section{CREED Steering Committee members include:}

Prof Johannes Opschoor, Institute for Social Studies, The Netherlands (Chair)

Prof Gopal Kadekodi, Centre for Multidisciplinary Development Research, India

Dr Ronaldo Seroa da Motta, IPEA, Brazil

Dr Mohamud Jama, Institute for Development Studies, Kenya

Dr Anantha K. Duraiappah, IVM, The Netherlands

Prof Harmen Verbruggen, IVM, The Netherlands

Joshua Bishop, IIED, UK

Maryanne Grieg-Gran, IIED, UK

Abstracts of CREED publications and details of all CREED projects

are now available on the Internet. Visit the CREED website at:

http://www.iied.org/creed 


\begin{abstract}
Many conflicts in numerous parts of the developing world can be traced to disputes over land ownership, land use and land degradation. In this paper we test the hypothesis that differences in knowledge structures on land tenure and market systems between different leaders within these countries has caused marginalisation of some leaders by the others. A sustained process of marginalisation driven by this inequality has caused the disadvantaged to revolt, resulting, in many cases, in violent clashes. In this paper we develop a game theoretic model to test our hypothesis by analysing the complex interdependencies existing among the various leaders in the Narok district in Kenya. Violent clashes have been increasing in the district since the first outbreak in 1993. Preliminary results seem to confirm our suspicion that differences in knowledge structures among the various leaders in over land and agricultural markets might have been the catalysts of these conflicts. In order to reduce these discrepancies, we recommend two institutional reforms. The first involves the adoption of a hybrid land tenure system whereby land ownership is based on individual titles, while the use and sale of the land is governed by communal rules established by a community participatory process. The second recommendation involves the formation of an information network comprising all leaders, with the main objective to provide a forum for exchange of ideas and information pertaining to land use options and the opportunities offered by the market system.
\end{abstract}

\begin{abstract}
Abrégé
Nombreux sont les conflits affectant bien des endroits du monde en développement, dont on peut retrouver l'origine dans des litiges portant sur la propriété foncière, sur l'utilisation des terres et sur la dégradation des sols. Dans ce document, nous testons l'hypothèse selon laquelle les différences de structuration des connaissances relatives aux tenures foncières et aux systèmes de marché - différences qui affectent divers leaders des pays concernés — ont abouti à la marginalisation de certains leaders par les autres. Un processus de marginalisation soutenu, mû par cette inégalité, a amené les plus démunis à se révolter, ce qui a donné lieu, en de nombreux cas, à de violents affrontements. Dans ce document, nous élaborons un modèle basé sur la théorie des jeux, afin de tester notre hypothèse en analysant les complexes relations d'interdépendance établies entre les différents leaders du district de Narok, au Kenya. Depuis la première explosion de violence de 1993, les affrontements n'ont fait que croître dans ce district. Nos résultats préliminaires paraissent confirmer notre hypothèse, à savoir que les différences constatées entre leaders quant aux structures de leurs connaissances sur la terre et sur les marchés agricoles pourraient bien avoir joué, pour ces conflits, un rôle de catalyste. Afin de réduire ces écarts, nous recommandons la mise en œuvre de deux réformes institutionnelles. La première consiste à adopter un sytème hybride de tenure foncière, où la propriété reposerait sur des titres de propriété privée d'ordre individuel, tandis que l'usage et la vente des terres seraient soumis à des règles communales, définies par un processus participatif communautaire. La seconde recommandation tient en l'élaboration d'un réseau d'information regroupant tous les leaders, avec pour principal objectif d'établir un forum pour l'échange d'idées et d'informations sur les options disponibles en utilisation des terres et sur les opportunités qu'offre le système du marché.
\end{abstract}

\title{
Resumen
}

Muchos de los conflictos en gran parte de los países en desarrollo tienen su origen en disputas sobre la propiedad, uso y deterioro de la tierra. En este artículo probamos la hipótesis de que las diferencias en las estructuras de conocimiento sobre tenencia de la tierra y sistemas de mercado entre diversos líderes en dichos países ha causado la marginalización de unos líderes por otros. Un proceso sostenido de marginalización producido por la desigualdad entre grupos ha hecho que los menos favorecidos se rebelen, en muchos casos violentamente. En este artículo se desarrolla un modelo de teoría de juegos para probar nuestra hipótesis analizando la compleja interdependencia entre los diversos líderes en el distrito Narok de Kenya. Los conflictos violentos han ido en aumento en este distrito desde el primer incidente en 1993. Los resultados preliminares muestran que las diferencias en las estructuras de conocimiento entre los diversos líderes con relación a la tierra y los mercados agrícolas pueden haber sido los catalizadores de dichos conflictos. Con el fin de reducir estas diferencias, se recomiendan aquí dos reformas institucionales. La primera implica la adopción de un sistema híbrido de tenencia de la tierra en el cual la propiedad esté basada en títulos individuales, mientras que el uso y la venta de la tierra se decida por regulaciones comunales establecidas mediante un proceso de participación comunitaria. La segunda recomendación involucra la formación de una red informativa que incluya a todos los líderes, con el objetivo principal de proporcionar una plataforma de intercambio de ideas e información relativa a las opciones de uso y a las oportunidades que ofrece el mercado. 


\section{Contents}

Introduction 1

An Overview of the Land Tenure, Land Use and

Land Degradation Nexus in the Narok Region

The Problem at Hand $\quad 6$

The Game Theoretic Model $\quad 7$

Solution Concept 9

Model Simulation and Results $\quad 11$

Group ranch system with institutional constraints on full leasing and with no instrumental rationality (GR-ICNIR) 11

Group ranch system with institutional constraints on full leasing but with limited instrumental rationality (GR-ICLIR) 12

Group ranch system with unlimited institutional constraints on leasing and with limited instrumental rationality (GR-NICLIR) 13

Group ranch system with unlimited institutional constraints on leasing and with full instrumental rationality (GR-NICFIR) 14

Group ranch system with no institutional constraint on full leasing but with fixed amount of land reserved for wildlife plus limited instrumental rationality (GR-NICWLIR)

Full land privatisation with limited instrumental rationality

(FP-LIR)

Policy Prescriptions and Implications $\quad 18$

$\begin{array}{lr}\text { Policy option 1 } & 19\end{array}$

Policy option $2 \quad 20$

Policy option $3 \quad 21$

$\begin{array}{ll}\text { Conclusion } & 23\end{array}$

$\begin{array}{ll}\text { Bibliography } & 24\end{array}$ 


\section{Introduction}

Many conflicts in numerous parts of the developing world can be traced to disputes over land ownership, land use and land degradation. The social unrest witnessed in Guatemala (Murga, 1997), Nicaragua (Powelson and Stock, 1990), Kenya (Kanyinga, 1998; Okoth-Ogenda, 1996), South Africa (Bullard and Waters, 1996), and India (Conroy et. al., 1998) all have common themes: land ownership and rights of use disputes, polarisation of economic and political institutions by a small elite and privileged class, and degradation of natural resource bases, all leading to growing inequality and poverty among certain communities. The precise nature of these disputes is still unclear, but an evolving theory of institutional failure and information asymmetries among communities is beginning to emerge (North, 1995; Bates, 1995). The premise of this new literature is as follows. Indigenous land ownership and land use systems were dismantled and replaced by private land ownership systems by colonial powers. The best lands were reserved exclusively for the colonists while the marginal lands were left to the indigenous populations. The new land institutions, coupled with the introduction of market economies to provide exchange mechanisms for the crops grown on the land, and further compounded by their having access only to marginal lands, led to fragmentation of the local communal societies and the rules which regulated and monitored land ownership, use and exchange.

With the arrival of independence in many of these countries, the land previously owned by the colonists was distributed by the new governments. In some countries the distribution was equitable, while in others a similar process of exploitation, condoned by the colonists continued, but with the privileged classes taking advantage of the distribution programme. Even in countries where equitable distribution programmes were implemented, the initial distribution patterns quickly collapsed with special groups buying out the poorer land owners, usually at very low prices. Many of these land owners either moved to the cities in search of employment or moved into marginal agricultural areas. The latter movements began a whole new process of environmental degradation as marginal lands came to be used intensively at rates far beyond the capacity of these areas. The dual process of exclusion and inhibition led to increasing levels of absolute and relative poverty simultaneously.

The increase in absolute poverty together with widening equity gaps in these countries established a rich environment for social unrest. This was further compounded by a collapsing political environment with the elite taking control, directly or indirectly, of the political institutions in these countries. Pushed into a vicious spiral and seeing no solution, many of the marginalised groups resorted to demonstrations which were often violent, causing casualties and damage. The solution seems simple: provide equal opportunities to all. However, the process is far from simple. First, there is reluctance on the part of the privileged to give up their positions. Second, many of the destitute might be unfamiliar with the prevailing economic and political institutions and might therefore have difficulty in taking advantage of any economic or political reforms. Rather than eradicating the present institutional structures and replacing them with new ones, what may be needed is gradual change driven by a participatory process involving all the leaders.

In this study, we propose to investigate the nexus between institutions, poverty, inequality and environmental degradation in an attempt to shed some light on the critical factors underpinning this, and to propose some possible policy designs. As the nexus is complex, and in many instances dependent on local conditions, we conducted our analysis at a district level 
rather than at national or regional level. The paper is presented as follows. In section 2 we provide an overview of the problem and possible reasons for the increasing frequency of violent conflicts among various leaders in the district. In section 3 the mathematical model developed for this study is presented. This captures the critical dynamics governing the nexus in the district. Results from various simulations of the model are presented in section 4 , while in section 5 we provide policy recommendations for institutional reforms. The paper ends with conclusions drawn from the lessons learned from this case study. These can be used in similar situations in other districts within the country as well as in other countries. 


\section{An Overview of the Land Tenure, Land Use and Land Degradation Nexus in the Narok Region}

The Narok district in Kenya has witnessed increasing levels of environmental degradation over the last decade (Ogolla, 1996; CBS, 1998; MNPD, 1997). Unsustainable deforestation, livestock, and farming activities have been identified as primary causal factors in the persistent deterioration of the quality of land in the district. Institutional and market failure, ranging from land tenure to government-influenced commodity markets, have been cited as the primary driving forces of these unsustainable economic activities (Pagiola, 1996; MigotAdholla,1994 and Duraiappah, 1998). In conjunction with environmental degradation, social welfare conditions have deteriorated in the district. Stakeholders who have been living in the area for generations have seen their lifestyle deteriorate. Land belonging to families or tribes for generations, has been lost to new stakeholders who have moved into the district. The continued displacement of people from their ancestral lands has resulted in a loss of access to resources by these people, which has inevitably caused a drop in income and for the majority has resulted in poverty.

Deteriorating environmental and social welfare conditions have resulted in an increase in conflicts between the indigenous inhabitants of the district and the newcomers, with violent and bloody outcomes in many cases. The solution is far from simple. The indigenous inhabitants claim that they are victims of a land tenure system of which they had little knowledge and have therefore been placed at a disadvantage in the land transactions which have taken place. They are now claiming proper remuneration for the lands they sold in the past. Taking advantage of the lax systems present at the time, many of the descendants of the families who had sold their land have been challenging these land sales in court.

This paper will not focus on lands already privatised, but will attempt to find equitable strategies for the large tracts of land, currently under trust status, but which are coming under increasing pressure to be privatised. In broad terms the Narok district can be categorised into two distinct geographical zones - the highlands and the lowlands. The highlands, characterised by rich volcanic soils with high rainfall, are defined as high potential areas (Jatzold,1982). The plains, on the other hand, are characterised by less fertile soils with lower rainfall patterns and are classified as mid to low potential areas. The highlands were covered predominantly with forest-type vegetation, while the plains are of savannah-type rangelands.

The Masai are the indigenous inhabitants of this district. They are, to a large extent, nomadic pastoralists who use the lowlands for their livestock during the wet season, and the highlands during the dry season, when they serve as critical relief zones (Dietz, 1996). The nomadic lifestyle implies a culture where land is treated as a communal property, while livestock is considered as individual or family wealth. With the arrival of white settlers in the early part of the twentieth century, a large portion of the highlands was appropriated by the colonists for agriculture. The Masai pastoralists were pushed into the lowlands and were prevented from accessing the highlands for their livestock. This appropriation and exclusion policy by the colonists laid down the foundations of the marginalisation process of the Masai pastoralists which has continued until the present day. In the 1950s and 1960s a series of land reforms, beginning with the Swynnerton tenure reform plan, was implemented. The objective was to give individual land titles to Kenyans, thus providing the driving forces behind a wealthy local farming community (Dickerman, 1989). In the Narok region, in addition to the general objectives of providing individual land ownership, another intention of the government was 
to settle the Masai, on the belief that the nomadic lifestyle was an inefficient use of land resources (Okoth-Ogendo,1996 and Galaty,1980). However, Table 1 clearly demonstrates a displacement of Masai pastoralists in the district and implies the transfer of land use and ownership from Masai pastoralists to non-Masai non-pastoralists.

The provision of individual land titles led a large number of the pastoralists to sell their land. The prospect of quick wealth, which could then be used to buy more livestock, was the driving force for the transfer of land ownership from Masai to non-Masai (Rutten, 1996). Inevitably, the purchase of more livestock in a situation where land was decreasing, particularly critical land, resulted in overgrazing and consequently land degradation. The combination of less land and more livestock culminated in an increase in livestock mortality rates, especially during drought years. This in turn caused many pastoralist families to suffer a drop in their income and wealth, and in many cases, they were pushed below the poverty line of US\$ 330 a year.

The majority of the new immigrants are from the Kalienjin and Kikuyu groups. Most of these immigrants are small-scale farmers who bought small parcels of land in the highlands, cleared the forest and planted a combination of food and cash crops. Another group, which had also taken advantage of the land reforms of the 1950s and 1960s, are large-scale commercial farmers of white and Asian descent. This group, wealthy and politically well connected, though much smaller in number, acquired large tracts of land for commercial farming of wheat and barley.

In the lowlands a similar situation was taking place. The lowlands with large tracts of flat and relatively fertile land, coupled with adequate rainfall, provided ideal conditions for the adoption of large-scale wheat farming. However, unlike in the highlands, only the large commercial farmers were present. The large economies of scale prevented the small-scale farmer from farming in this area. Although land ownership in the plains remained with the Masai pastoralists under the group ranch land tenure system, many of the commercial farmers were able to secure attractive lease terms for the use of the land. The expansion of wheat farming in the lowlands has forced the pastoralists to move deeper into the lowlands.

Table 1: Population demographics in the Narok region

\begin{tabular}{|c|c|c|c|c|c|c|}
\hline Year of census & 1948 & 1962 & 1969 & 1979 & 1989 & 1997 \\
\hline Total population & 37000 & 101000 & 125000 & 210300 & 398000 & $576000^{1}$ \\
\hline Percentage Masai & 99 & 95 & 85 & 56 & 47.3 & $\mathrm{n} / \mathrm{a}^{2}$ \\
\hline Percentage non-Masai & 1 & 5 & 15 & 44 & 52.7 & $\mathrm{n} / \mathrm{a}^{2}$ \\
\hline Density no $/ \mathrm{km}^{2}$ & 2.5 & 6.9 & 8.6 & 14.5 & 27.4 & 44 \\
\hline Land per capita & 0.39 & 0.14 & 0.12 & 0.07 & 0.04 & 0.03 \\
\hline
\end{tabular}

However, displacement into the lowlands is facing increasing constraints. Under increasing pressure from international as well as domestic NGOs, the government has adopted a strategy of reserving large tracts of land in the plains for wildlife, unlike in the past where the Masai and wildlife coexisted in harmony. Consequently, as Figure 1 demonstrates, a combination of displacement from both the highlands and the outer plains had, in essence, boxed the pastoralists into a narrow corridor with very little manoeuvrability. 
Figure 1. The Narok District

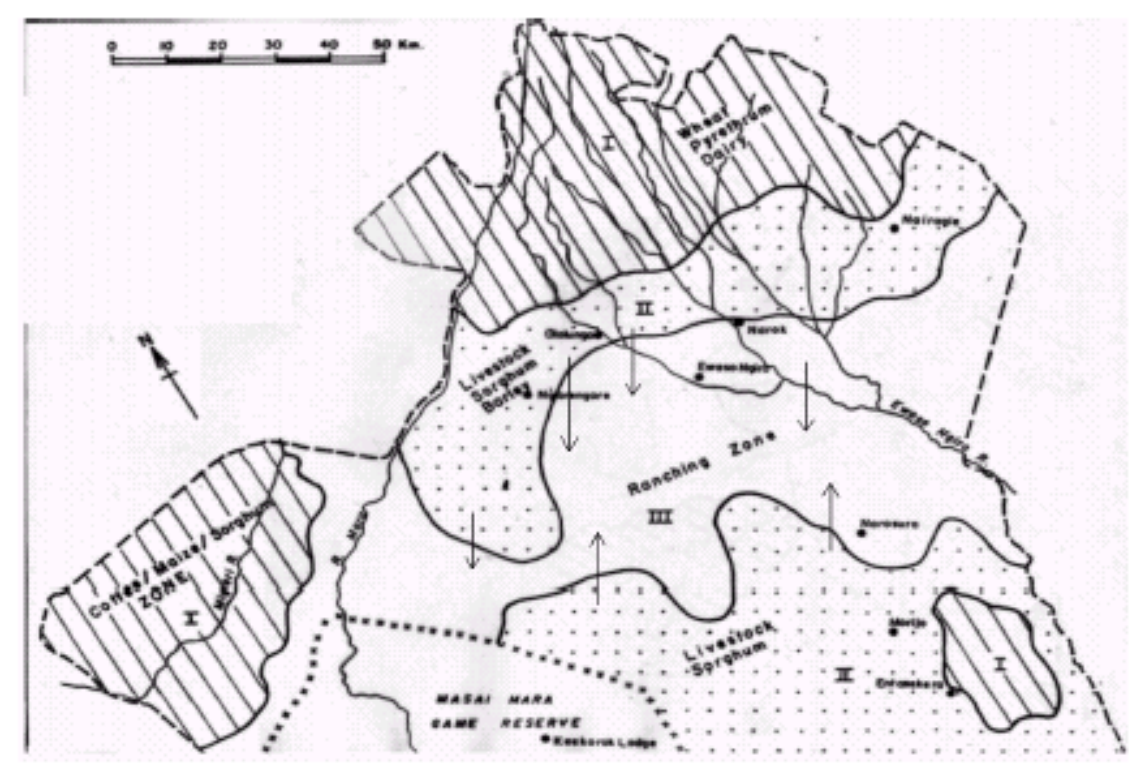

Recently the main disputes have been between the Masai pastoralists and immigrant farmers in the highlands (Shipton,1988 and Okoth-Ogenda, 1996). Due to their low income and low social status, the immigrants provided the logical targets for the pastoralists' anger and resentment. Although in reality, the large commercial farmers have been acquiring large tracts of land, very little attention has been focused on them by the Masai pastoralists. First, these farmers primarily lease the land from the pastoralists. Second, political clout as well as economic power has shielded this group from the resentment of the pastoralists, whose small number compared with that of the migrant farmers minimises the impact of their presence and actions. 


\section{The Problem at Hand}

The present issue revolves around trust land, which is owned by Masai pastoralist groups. There is increasing pressure to privatise these trust lands, transfer ownership to the individual families within the groups and let the families decide on the use of the land. However, many critics of this policy option fear a repetition of the series of events which occurred in the ' $60 \mathrm{~s}$, when land titles were given to individuals in the highlands. This led to a massive sale of land to outsiders, and in turn resulted in the displacement of the Masai pastoralists.

However, supporters of the privatisation policy argue that privatisation would decrease the rate of land degradation occurring on leased land. If individual families are given their own pieces of land, then there is an incentive to conserve it, either for their own use or for sale to the farmers. A second argument in favour of privatisation is that under the present system, many of the families within a group do not share the proceeds of the land, and only a few individuals reap the benefits. With individual titles, the proceeds of the land would be enjoyed directly by the individual families.

There are basically three policy options open to policy-makers. The first is to continue with the present group ranch system. The second is to privatise the land and let the land-owners decide on the use of the land. The third option is to adopt a unique combination of the first two options. The outcomes of these options are presented later in the paper. We now present the mathematical model developed for this study which captures the essential dynamics of the present situation in the Narok district. 


\section{The Game Theoretic Model}

We begin by identifying an objective function for each group of agents. We assume there are $n$ groups of agents. For the sake of simplicity, we used a simple profit maximisation function as the objective for each of the agent groups. In this way we capture the economic activities of each group and the dependency of their objectives on the natural system, which in this case is land. Each group then maximises this objective according to the environmental constraints they face. The objective function is of the form

$$
\max _{d_{i}^{\mathrm{s}}, d_{i}^{l}, q_{1}, \ldots, q_{n}} \pi_{i}=\sum_{t=1}^{T} \delta_{i, t} r_{i, t}
$$

where the intertemporal revenues are determined according to the equation

$$
r_{i, t}=\sum_{\substack{j=1 \\ j \neq i}}^{n} p s_{i, t} d s_{j, t}^{i}+\sum_{\substack{j=1 \\ j \neq i}}^{n} p l_{i, t} d l_{j, t}^{i}+p_{i, t}^{u}\left(1-\phi_{i, t}\right) q_{i, t} d_{i, t}^{u}
$$

The above revenue function consists of three parts. The first relates to revenues from land sales. The term $d s_{j, t}^{i}$ is the amount of land sold by agent $i$ to agent $j$ at time $t$. The second term refers to lease revenue, where $d l_{j, t}^{i}$ is the amount of land leased out by agent $i$ to agent $j$ at time $t$. The third item relates to revenue earned from economic activity by agent $i$ using his own piece of land. The term in brackets adjusts actual production from expected production - the difference stemming from land degradation activities adopted by agent $i$. The level of degradation is measured by the variable $\phi_{i, t}$. The term $q_{i, t}$ denotes the output per hectare which can be set by agent $i$.

We want to allow for the possibility that agent $i$ buys or is able to lease land in. In these cases the terms $d s$ and $d l$ are negative. When player $i$ leases land in, his intertemporal revenue will be slightly different compared with equation (2). When there are $d_{i_{\pi} t}^{\dot{j}}<0$ (leasing land in) then

$$
\begin{aligned}
r_{i, t}= & \sum_{\substack{j=1 \\
j \neq i}}^{n} p s_{i, t} d s_{j, t}^{i}+\sum_{j=1}^{n} p l_{i, t} d l_{j, t}^{i}+p_{i, t}^{u}\left(1-\phi_{i, t}\right) q_{i, t} d_{i, t}^{u} \\
& -\sum_{\substack{j=1 \\
j \neq i}}^{n} p_{j, t}^{u}\left(1-\phi_{j, t}\right) q_{j, t} d l_{i, t}^{j}
\end{aligned}
$$

The fourth item is similar to item three but this is revenue earned by agent $i$ on leased land. The output is again corrected for land degradation. The prices $(p s)$, the price of land $(p l$, ) the price of leasing, and the price of livestock $(p u)$ are fixed. The land-stock-accumulation equation is defined as 


$$
d_{i_{n} t}^{o}=d_{i_{n} t-1}^{\sigma}-\sum_{\substack{j=1 \\ j \neq i}}^{n} d s_{j, t}^{i} \quad d_{i_{n} t}^{\infty} \geq 0
$$

The land owned by agent $i$ at end of each time period $t$ is equal to land owned at the end of the last time period, minus or plus land sold or bought to or from all other agents in time period $t$. This equation keeps track of land ownership by the various groups. The initial land endowment $d_{i, 0}^{o}$ is given. The level of land used by agent $i$ of his own land is defined as

$$
d_{i, t}^{u}=d_{i_{n} t}^{o}-\sum_{\substack{j=1 \\ j \neq i}}^{n} d l_{j_{n} t}^{i} \quad d_{i_{n} t}^{u} \geq 0
$$

The amount of land which is used by agent $i$ is equal to the total land owned minus or plus all land leased out or in respectively by the agent. Consequently, the land sale balance equation is equal to

$$
\sum_{i=1}^{n} \sum_{\substack{j=1 \\ j \neq i}}^{n} d s_{j, t}^{i}=0
$$

Hence, total land sales must add up to zero. Similarly, the land lease balance equation

$$
\sum_{i=1}^{n} \sum_{\substack{j=1 \\ j \neq i}}^{n} d l_{j, t}^{i}=0
$$

should also hold as all land leased out by agent $i$ to all other agents must be equal to all land leased in by all other agents from agent $i$. Land degradation on agent I's land is assumed to follow a logistic process

$$
\phi_{i, t}=\frac{1}{1+e^{\frac{q_{i, t}^{a v g}}{q_{i, t}}}}
$$

where

$$
q_{i, t}^{a v g}=q_{i, t} \quad \text { if } \quad \forall j \quad d l_{j, t}^{i} \leq 0
$$

and

$$
q_{i, t}^{a v g}=\frac{q_{i, t} d_{i, t}^{u}+\sum_{\substack{j=1 \\ j \neq i}}^{n} q_{j, t} d l_{j, t}^{i}}{d_{i, t}^{u}+\sum_{\substack{j=1 \\ j \neq i}}^{n} d l_{j, t}^{i}} \text { if } \quad \exists j \quad d l_{j, t}^{i}>0
$$

The variable $\phi_{i_{n} t}$ is the degradation component caused by agent $i$ on his own piece of land. If the output $q_{i_{n} t}$ (output/hectare on his own land) is higher than the carrying capacity at time $t$, then an efficiency loss in the form of a degradation factor occurs. We use a logistic function to capture this. The $q_{i, t}^{a v g}$ basically captures the joint degradation effects of both the owner of the land and the lessee if any. The land carrying capacity is defined as 


$$
\bar{q}_{i, t}=\left(1-\phi_{i, t-1}\right) \bar{q}_{i_{,} t-1}
$$

Equation (11) captures the time varying carrying capacity of the land. For agent $i$ through the value of $\phi_{i, t-1}$, the degradation of his land is a combination of the degradation he caused plus the degradation other agents caused on the land he leased out to all other agents. The final carrying capacity is therefore a weighted average of the various degradation levels. The upper limit on land carrying capacity

$$
\bar{q}_{i, t} \leq \bar{q}_{i_{z}} \bar{o}
$$

This equation imposes a constraint that carrying capacity is always equal to or below the optimal level, which is assumed to be the level in period zero.

\section{Solution concept}

In the previous sub-section we presented the mathematical formulation of the gametheoretical model we will use to analyse the poverty-environmental degradation effects in the Narok district. The model we will be using consists of three agent groups $(n=3)$ : the commercial farmers, the mixed farmers and the Masai pastoralists. Each of these agent groups optimises their objective function as described in equation (1) subject to their, agent $i$ specific constraints, equations (2)-(5) and equations (8)-(12). Furthermore, there are two general constraints, equations (6)-(7), which should hold for the agents as a group. These two equation superimpose market clearing. The way we have modelled the market clearing mechanism reflects the actual situation in the Narok district. In the current situation the Masai pastoralists provide the commercial farmers with the amount of land they require for their activities, while the prices are quasi-fixed.

For our simulations we are applying a closed loop Nash-equilibrium concept. The reason for this is that we are interested in the dynamic interaction effects that come from the land degradation. Given the non linearities in the model it is not possible to compute the closed loop analytically. Hence, we need an iterative scheme that produces the closed loop solution. For our iterative scheme we start out with a open loop solution of the model given the initial set of endowments available to the players. In a second iteration we recompute the optimal strategy of each player for the entire planning horizon, given the change in the endowments and degradation-spillover effects. Schematically this leads to the following algorithm in pseudo-code

1. Set all parameters of the model, iteration count $j=0$

2. Set $x_{i}^{j}$ to an initial value, set maxeps, maxiter

3. For $j=1$ to maxiter

4. For $i=1$ to 3

5. $\operatorname{Max}^{\Pi_{i}^{j}}$ subject to the relevant constraints

6. next $i$

7. Compute norm

$$
\forall i \epsilon_{i}=\frac{x_{i}^{j}-x_{i}^{j-1}}{x_{i}^{j}}
$$

8. If $\epsilon_{i} \leq$ tolerance stop; convergence reached

9. next $j$ 
where the vector $x_{i}^{j}$ contains the stacked variables over which the agent $i$ maximises its objective function. In steps 0 and 1 all the crucial parameters and initial endowments, the amount of land, and the convergence criteria of the model are initialised. The main loop starts in steps 2-8. In this loop we repeat the maximisation process of each player, steps 3-5, until convergence is reached for the Nash solution. This loop is necessary as each player's action produces environmental spill-over effects that affect the other players' actions. To fully capture these spill-over effects, we have to repeat the optimisation steps 3-5 until each player's action fully take into account these effects. As already mentioned the above approach produces a closed loop Nash solution of the game-theoretical model.

Table 2: Business as usual

\begin{tabular}{lccc}
\hline Item & Masai & Commercial farmers & Mixed farmers \\
\hline Revenues per year (million Ksh) & 658 & 668 & 1026 \\
Degree of Land degradation as $\%$ & 3.5 & 96 & 0 \\
Land leased per year (hectares) & 55400 & -55400 & 0 \\
Annual revenues per capita (Ksh) & 6325 & 3300000 & 16193 \\
& (US\$ 105) & (US\$ 55000) & (US\$ 270) \\
\hline
\end{tabular}

${ }^{1}$ We compute income per capita using population data provided in Table 1 . We assume that in 1997 there is a 45-55\% distribution between Masai and non-Masai respectively and each household has approximately five members. We start with 7,200 Masai households in 1979. Multiply by 3 (population growth factor) to get the 1998 figure of 22,000. For mixed farmers we get 12,000. The number of commercial farmers is based on 40 farms. 


\section{Model Simulation and Results}

By using the model from the previous paragraph we carried out five simulations. The first simulation, called Group Ranch System with Institutional Constraints on Full Leasing and with No Instrumental Rationality ${ }^{1}$ (GR-ICNIR), depicts the present situation. We use the GRICNIR as the point of departure and run a series of simulations where we change the land tenure regime and the information structure in a number of ways which mimics various policy options which can be implemented by policymakers in response to the present issues at hand. In the first three simulations, we assume no changes in land tenure policy (i.e. the group ranch system is maintained), but changes in information structures are carried out. In the last simulation, a full land tenure privatisation policy experiment is implemented, but under present information structures, as strongly advocated by policymakers. In this way, we can observe how costs and benefits vary under the various policy options, and inevitably provide the platform for policy recommendations and their implications.

\section{Group ranch system with institutional constraints on full leasing and with no instrumental rationality (GR-ICNIR)}

In this scenario we adopt a land tenure system and an information structure which closely resembles the current situation in the Narok district. In this simulation, the following assumptions are imposed on the information structure underlying the model. First, lessors do not have knowledge of the environmental damage caused by lessees and therefore do not impose a compensation penalty. Second, the lessors do not know the market clearing lease price for land and accept fixed prices set by the lessees. In order to capture the group ranch land tenure regime, we adopted the following assumptions. First, no sale of land is allowed. Second, the amount of land leased out by the group ranches is restricted to the present level of $550 \mathrm{~km}^{2}$.

The income per capita levels shown in Table 2 highlight high degrees of income inequality among the three groups. The pastoralists experience both the lowest total income as well as income per capita. The mixed farmers do a little better by earning incomes around US\$ 270 a year; but this still leaves them below the poverty line of US\$ 330. However, a word of caution is necessary before any final conclusions can be made on the poverty status of the mixed farmers. A household survey conducted during this project revealed that mixed farmers get approximately $29 \%$ of total income from outside sources ${ }^{2}$. The adjusted figure of approximately US\$ 380 then puts them just above the poverty line. However, 'just above the poverty line' highlights the high degree of vulnerability this group finds itself in, being forced into destitution at the slightest disruption to their income stream. The continuation of the present state of violent conflicts would definitely constitute one form of disruption which can and will cause this group to fall into poverty.

Commercial farmers, as expected, experience the highest income per capita. It is observed that they also cause the highest rate of land degradation. Two factors explain this.

First, commercial farmers do not own the land they farm and therefore have no incentive to

\footnotetext{
${ }^{1}$ The instrumental rationality postulate of neo-classical theory assumes that the agents have information to evaluate correctly the alternatives, and consequently, make choices that will achieve the desired ends. See North (1990).

2 The Welfare Monitoring Survey II of 1994 also reports similar income demographies for the district (CBS 1996).
} 
adopt sustainable farming techniques. Second, they do not have to pay any form of compensation to the lessors for the land degradation they cause.

The mixed farmers, on the other hand, do not apparently carry out activities that would lead to degradation of their land. This is not surprising as they own the land and such activities would only reduce the future potential output of the land, which inadvertently implies a reduction in future revenue streams.

Like the mixed farmers, the pastoralists show very low levels of land degradation. However, this is a far cry from reality and in fact recent statistics show a high rate of degradation caused by overstocking livestock (MPND,1997). The dichotomy between model results and what is happening on the ground can be explained as follows. If we take the original land held by the Masai pastoralists $\left(9,500 \mathrm{~km}^{2}\right.$ which includes the highlands plus the land currently leased out for commercial farming), and compute the herd size which can be supported, we get livestock numbers corresponding to their present levels (500,000 LSU). This would seem to suggest that the pastoralists have not adjusted their livestock numbers to fit within their present land holdings $\left(8,350 \mathrm{~km}^{2}\right)$. The high livestock levels, which inevitably cause serious land degradation, lead to high livestock mortalities, especially during critical periods of drought. This may explain the present resentment of the pastoralists.

\section{Group ranch system with institutional constraints on full leasing but with limited instrumental rationality (GR-ICLIR)}

In our first attempt to find an equitable solution to the present deteriorating social and economic welfare of the pastoralists, we begin by maintaining the present group ranch tenure system but allow a feedback mechanism whereby a lessor has full information on the degree of land degradation caused by the lessee. We use the concept of opportunity cost to compute the penalty to be imposed by the lessor on the lessee if land degradation is observed. We call this payment a land degradation tax and the mechanism 'variable pricing'. The unique strength of this mechanism is that the lessee has control over the degree of degradation and therefore adopts an optimal level of farming intensity and land degradation based on economic costs and benefits.

The flexible price mechanism has two components. The first, the base component, is determined ideally by supply and demand forces of the market. The second component refers to the environmental degradation cost. In this simulation exercise, the lessor has knowledge of the latter but still lacks information on the former. Therefore, the base price for leasing a hectare of land is fixed at the prevailing rate of 5,800 Kenyan Shillings (KSh.) per hectare, and the flexible component is endogenous and determined in the optimisation process. The final price paid by lessors in this experiment is found to be approximately 7,000 Ksh. This implies an environmental cost of 1,200 Ksh. per hectare imposed on the lessee by the land owner. This is, of course, based on the assumption that the institutions for monitoring and enforcing the lease contracts are in place and operating efficiently. However, this assumption may not hold for Kenya or, in fact, for

many developing countries where the judicial and administrative institutions have been compromised. In the section on policy recommendations in this paper, we discuss some possible institutional modalities to address this gap.

The commercial farmers experience a significant drop in income under the flexible pricing mechanism. This is primarily caused by an adjustment downward of yields to levels which 
minimise degradation. The pastoralists, on the other hand, experience some gain in their incomes. These gains come from the compensation they receive for the environmental degradation caused by the commercial farmers on their land. However, as the results in Table 3 illustrate, the increase in income is insufficient to get them over the poverty line. Clearly, more needs to be done.

\section{Group ranch system with unlimited institutional constraints on leasing and with limited instrumental rationality (GR-NICLIR)}

In this scenario we relax the constraint on the amount of land leased out by the Masai pastoralists, thereby allowing commercial and mixed farmers the possibility of leasing all 'potential agricultural land'. By using the term 'potential agricultural land', we implicitly model the following information structure: farmers, in particular the commercial farmers (the lessees in this case), have full knowledge of land quality and therefore limit their leasing options to potential agricultural land which, in this case, turns out to be 550,000 hectares of the total area of 835,000 hectares (Jaetzold, 1979). The institutional constraints faced by the lessors is lifted. The modifications to the existing institutions is discussed later in the paper. The final assumption adopted in this simulation is that lessors have full knowledge of the land degradation activities of the lessees.

From Table 4 we observe that commercial farmers lease all potential agricultural land available. As expected, revenues for the pastoralists and the commercial farmers increase significantly because of the larger parcel of land being made available and consequently used for agriculture. The degree of degradation goes down in comparison to GR-ICNIR, but goes up by $2.3 \%$ as compared to GR-ICLIR. The reason for the slightly higher degree of degradation is because access to a larger acreage of land allows some flexibility on the part of the commercial farmers over their degradation activities. The rule commercial farmers adopt is a simple one: degrade until the marginal costs of degradation is equal to the marginal revenue earned from the degradation activities.

The revenues received by the pastoralists under this scenario push them well above the poverty line. The pastoralists find the option of leasing out all potential agricultural land to the commercial farmers at present prices, plus a flexible component adjusted for environmental degradation, to be far more beneficial than using the land for pastoralism. But it should be borne in mind that the lessors are still operating under a limited instrumental rationality environment. They have no information on the land lease prices and on whether the present 5,800 Ksh per hectare is a market clearing price or whether higher prices could be achieved. It is to this question that we turn our attention next.

Table 4: Group ranch system with no institutional constraints on full leasing and with limited instrumental rationality (GR-NICLIR)

\begin{tabular}{lccc}
\hline Item & Masai & \multicolumn{2}{c}{$\begin{array}{c}\text { Commercial } \\
\text { farmers }\end{array}$} \\
\hline Revenues per year (million Ksh) & 3290 & 1906 & Mixed farmers \\
Degree of land degradation as \% & 3 & 3 & 1026 \\
Land leased per year (hectares) & 550000 & -550000 & 0 \\
Annual revenues per capita (Ksh) & 31634 & 9530000 & 0 \\
& (US\$ 527) & (US\$ 158800) & (US\$ 270) \\
\hline
\end{tabular}


Table 5: Group ranch system with no institutional constraints on full leasing and with full instrumental rationality (GR-NICFIR)

\begin{tabular}{lccc}
\hline Item & Masai & $\begin{array}{l}\text { Commercial } \\
\text { farmers }\end{array}$ & Mixed farmers \\
\hline Revenues per year (million Ksh) & 4169 & 523 & 1026 \\
Degree of land degradation as \% & 3 & 3 & 0 \\
Land leased per year (hectares) & 550000 & -550000 & 0 \\
Annual revenues per capita (Ksh) & 40089 & 2616744 & 16193 \\
& (US\$668) & (US\$ 43612) & (US\$ 270) \\
\hline
\end{tabular}

Group ranch system with unlimited institutional constraints on leasing and with full instrumental rationality(GR-NICFIR)

The ideal framework for answering this question will be to solve the game theoretic model in a Walrasian general equilibrium framework and observe the land market clearing prices. However, modifying the existing model is a complex process. A short cut procedure was therefore adopted, whereby a trial and error process mimicking a general equilibrium or full instrumental rationality environment was adopted. The land market clearing price at which farmers stop leasing land was found to be $9,100 \mathrm{Ksh} /$ hectare. This is approximately double the present price of $5,800 \mathrm{Ksh}$. The benefits observed by the pastoralists increase by approximately $27 \%$ from annual revenues of US\$ 527 per capita to US\$ 668 per capita.

What is holding down the price? We isolated two factors which can explain the low prices. First, there may be evidence of a monopsony market for land in the district. Second, a lack of information on the true value of land on the part of the lessors could provide the lessees with bargaining power. In all probability, a combination of the two explains the low price.

\section{Group ranch system with no institutional constraint on full leasing but with fixed amount of land reserved for wildlife plus limited instrumental rationality (GR- NICWLIR)}

In our previous simulations, we did not discuss eco-tourism and the potential revenues which can be earned from this activity. However, to ignore wildlife tourism would be to ignore a potentially large source of income. Moreover, the option of converting a large portion of the land for agricultural activities as illustrated in the previous exercise, inadvertently implies the obliteration of wildlife in the area. Therefore, in order to investigate the costs and benefits associated with wildlife preservation, but without adding to the complexity of the model, we modelled eco-tourism as an economic alternative for the pastoralists.

We begin by computing the minimum amount of land that needs to be set aside if eco-tourism is to be adopted. Using the land categorisation system developed by Jaetzold \& Schmidt (1982), we computed a land area of approximately 380,000 hectares. In economic terms, this means that in order to earn a single dollar from eco-tourism, this relatively large tract of land has to be set aside. The interesting twist to this option is that approximately $900 \mathrm{~km}^{2}$ of potential agricultural land now needs to be set aside for wildlife. 
Table 6: Group ranch system with no institutional constraints on full leasing but with fixed amount of land reserved for wildlife plus limited instrumental rationality (GRNICWLIR)

\begin{tabular}{lccc}
\hline Item & Masai & \multicolumn{2}{c}{$\begin{array}{c}\text { Commercial } \\
\text { farmers }\end{array}$} \\
\hline Revenues per year (million Ksh) & 2624 & 1858 & Mixed farmers \\
Degree of land degradation as \% & 0.3 & 0.3 & 1026 \\
Land leased per year (hectares) & 460000 & -460000 & 0 \\
Annual revenues per capita (Ksh) & 25230 & 9290000 & 0 \\
& (US\$ 420) & (US\$ 154800) & (US\$ 270) \\
\hline
\end{tabular}

Table 7: Full land privatisation with limited instrumental rationality

\begin{tabular}{lccc}
\hline Item & Masai & $\begin{array}{l}\text { Commercial } \\
\text { farmers }\end{array}$ & Mixed farmers \\
\hline Revenues per year (million Ksh) & 6091 & 4545 & 1026 \\
Degree of land degradation as \% & 2 & 3 & 0 \\
Land leased per year (hectares) & see figure 3 & see figure 3 & 0 \\
Annual revenues per capita (Ksh) & 56884 & 2686000 & 16193 \\
& (US\$ 948) & (US\$ 5372000) & (US\$ 270) \\
\hline
\end{tabular}

We see from Table 5 that the pastoralists experience a drop in revenues if eco-tourism is adopted as an option. This is to be expected, as we do not include revenues accruing from eco-tourism in the profit function of the pastoralists. The question we ask in this study is, what gate price needs to be charged if this option is to be adopted by the Masai pastoralists? In other words, what gate price needs to be set to ensure that it makes no difference to the pastoralists whether land is leased out for farming or land is reserved for wildlife. The difference in revenues between leasing all potential agricultural land and reserving a part for wildlife is about $666(3290-2624)$ million Ksh. We estimate the number of tourist days available in a year to be about 100,000, see Norton-Griffits (1995). These figures suggest a gate fee of 6,660 Ksh or US\$ 111 per tourist per day (about five and half times the present rate of US\$ 20) needs to be charged in order to persuade the pastoralists to conserve the wildlife in the district.

\section{Full land privatisation with limited instrumental rationality (FP-LIR)}

The results from the last four simulation exercises have shown us the effects various policy measures initiated under the present group ranch system can have across the different leaders in the district. However, some of the leaders have been placing increasing pressure on policymakers to dismantle the group ranch system and fully privatise the land. We ran such a scenario and the results presented below illustrate the impact this policy would have on the various leaders. The knowledge base we adopt for this simulation is as follows. First, the pastoralists have no information over the 'actual' or more appropriately, 'potential' value of the land, and accept prices as offered by the buyers, in this case the commercial farmers. Second, based on their past experience, the commercial farmers have full information about the value, and have knowledge of land quality and the availability of potential agricultural land. In the event, land is leased out rather than sold, and the lessor has full knowledge of the degradation activities of the lessee. 


\section{Figure 2: Revenue profile under unrestricted sale of land}

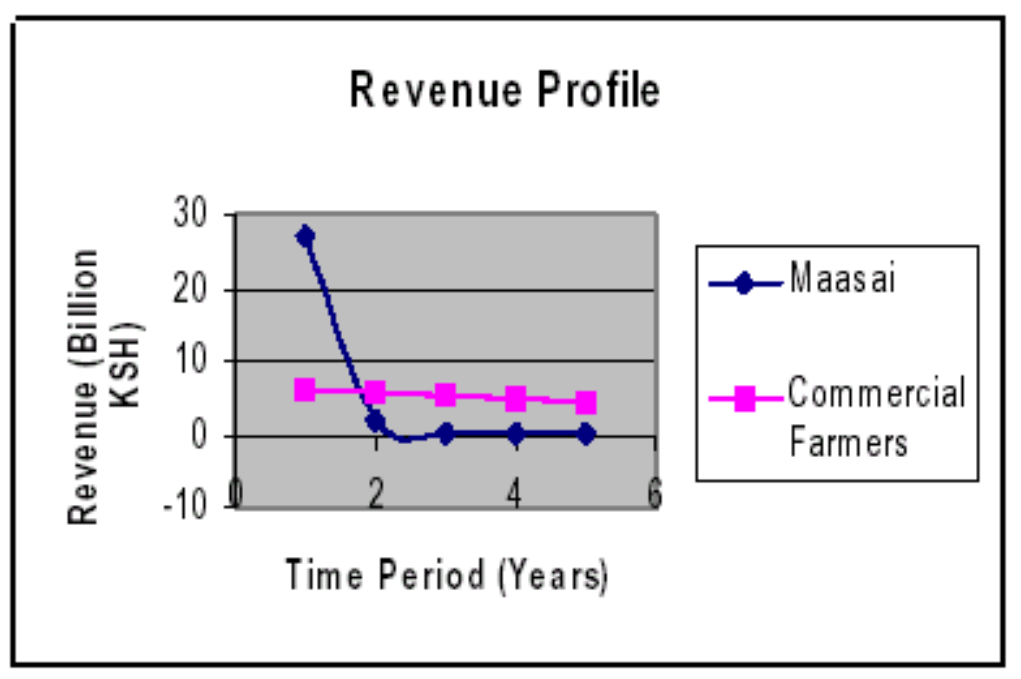

Both the pastoralists and the commercial farmers see a dramatic increase in their revenues (see Table 6). The commercial farmers opt for buying all potential agricultural land rather than leasing it from the pastoralists, and in return the pastoralists are eager to sell and not lease. Land degradation is also observed to be negligible as it is beneficial for the commercial farmers to conserve the land as it is now owned by them. These results would all seem to support the proponents of the privatisation policy. However, the results require closer scrutiny before any concluding policy prescriptions can be made. The annual incomes reported here were computed by finding the average over the five-year time period. This average income stream was observed to be close to the annual income stream in the previous simulations. However, this was observed not to be the case in this simulation. In Figure 2 we observe the pastoralists receiving a lump sum payment in the first two periods, but then receiving minimal income over the remaining periods of time. On closer inspection of the land ownership profile (see Figure 3), we observe the very phenomenon feared by critics of the privatisation policy - a massive sell-off of land within the first period by the pastoralists. This simulation demonstrates that if full privatisation is pursued, history can be expected to repeat itself $f^{3}$. Unless the lump-sum-payment is invested in assets which yield returns of 10.5 $\%$ (real) or higher, the pastoralists will, in fact, face what Rutten (1992) emphasises in his book, 'Selling Wealth to buy Poverty'.

A further consideration we need to address are the implications of the full privatisation policy on wildlife. As shown in Figure 3, all potential agricultural land is sold. This, in essence, leaves approximately 280,000 hectares for wildlife and livestock. As mentioned earlier, 380,000 hectares are required if wildlife is to be conserved. Two factors will definitely force the annihilation of wildlife in the district. First, there is a shortfall of 100,000 hectares. Second, we can expect the pastoralists to use the remaining 280,000 hectares for their livestock and, judging by past experiences, we can expect them to continue with their present livestock levels but in a much smaller area, inevitably leading to competition with wildlife for a rapidly deteriorating food source. We predict two outcomes if this policy is pursued. First, the pastoralists will be further marginalized and the present state of conflicts can be expected to escalate. Second, wildlife in the district will very quickly be obliterated.

\footnotetext{
${ }^{3}$ A similar series of events was witnessed in the neighbouring Kajiado District (Rutten, 1992)
} 
Figure 3: Land transfer profile under unrestricted sale of land

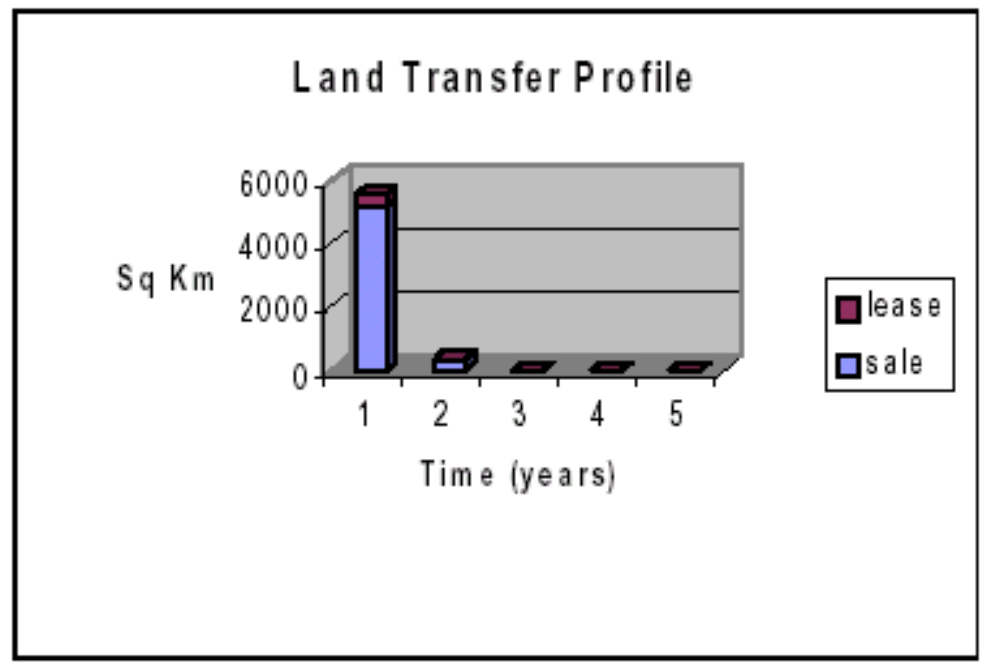




\section{Policy Prescriptions and Implications}

The results presented in the previous section have shown how welfare levels of the various leaders change depending on their information structures and land tenure systems. A surprising result, and yet not so surprising under closer scrutiny of the problem, is that the mixed farmers are passive players in the game. The model results show that they do not have the resources to compete with the commercial farmers for land. On the other hand, results from the first simulation (GR-ICNIR) provide some plausible reasons why they, the mixed farmers, have aroused the resentment of the pastoralists. The acquisition of lands in the highlands by the mixed farmers during the 1960s meant the loss of critical land for the pastoralists, especially during the dry season. In fact, comparing the present livestock levels with the amount of land available, the numbers suggest that, if land presently under mixed farming is used for pastoralism, then there would be no over-stocking or degradation of the resource base as presently observed in the district. However, to confiscate the land from the mixed farmers and give it back to the pastoralists is not a viable solution. It would only cause more problems and conflicts, because this policy would imply uprooting large segments of the population and moving them to other areas, inevitably establishing the same conditions for conflict but now in another district. A better solution is needed!

\section{Figure 4: Pay-off tree diagram for the various strategy choices}

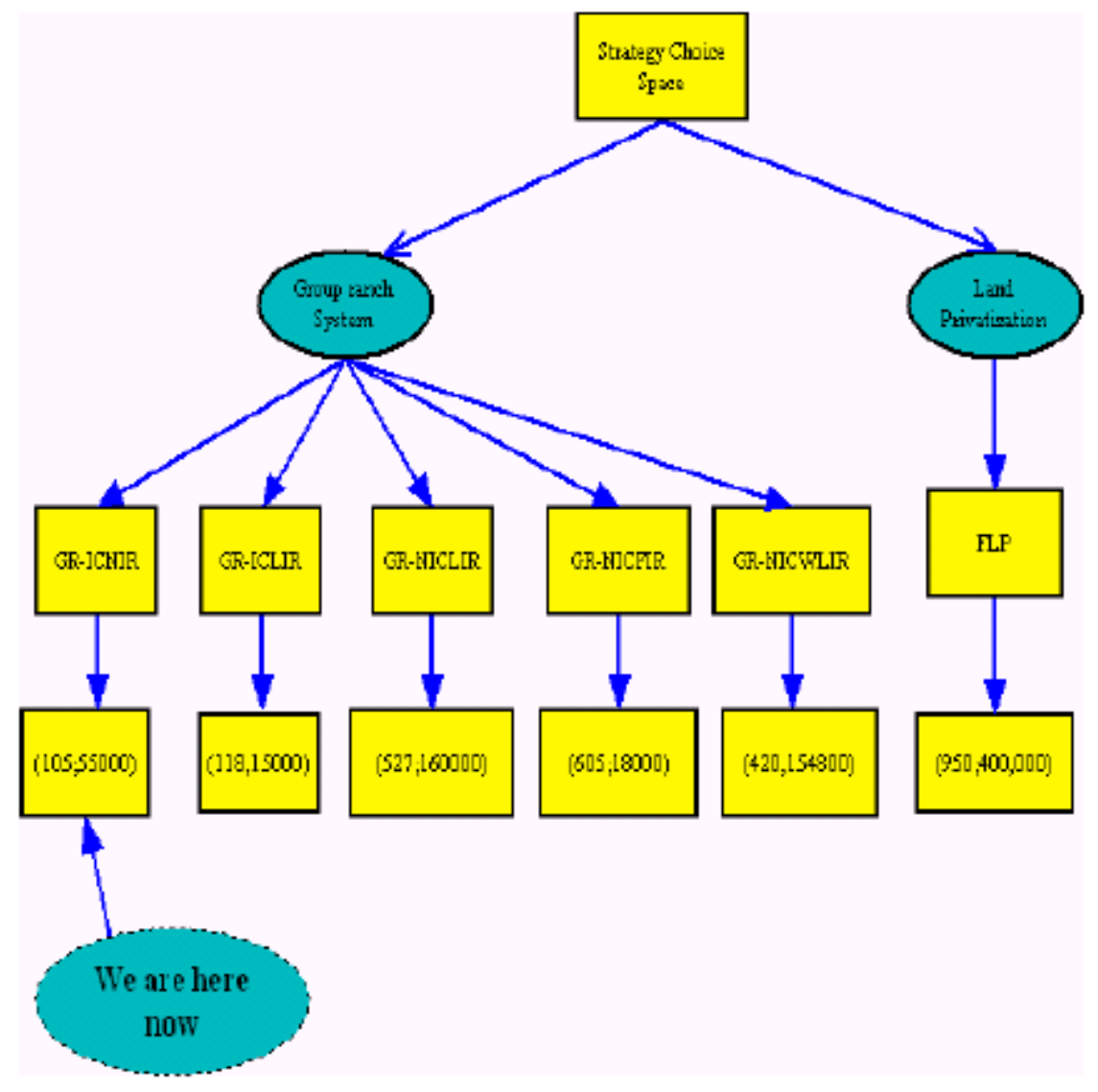

We start with the basic premise that improvements in the social welfare of the pastoralists and a reduction of the equity gap between them and the other leaders in the district will go a long way to reduce the tensions in the district and resolve the present state of violent 
conflicts. We acknowledge that because of political interests and ethnic differences, the conflicts might continue, but we believe that the conditions for these two forces to work effectively will be greatly reduced. The motivation and incentives to cause disturbances can be removed, or at least greatly reduced, if conditions are such that any disturbance will cause a deterioration in welfare levels, not only of the victims but also of the perpetrators.

It has been cited by institutional economists (North, 1995; Bates, 1995) that the clash between new institutions (private rights and the market), introduced and imposed by colonial powers, has been responsible for: (1) violent conflicts between different groups of people within the country; (2) increasing incidences of poverty; and (3) high rates of environmental degradation. The problems begin when inequality and disparity between and within various groups start to materialise. Some groups or individuals within groups, who are intellectually and politically more astute, have been able to adapt to and take advantage of the new system and its rules and regulations. Other groups, still working and living under the rules and regulations of the old systems, cease to work efficiently under the new institutional settings and are therefore marginalised by the process. The situation is exacerbated when the communal institutions which provided the safety nets in the past are systematically destroyed by the new institutional structures. This section is concerned in particular with land tenure and land use systems, and with identifying an institutional structure that contains elements of the new and old systems, such that it harnesses the strengths of both while at the same time protecting the interests of all groups. It is with this aim that the discussion focuses on policy options and recommendations.

In Figure 4 we present the pay-offs received by the two main players in the game, pastoralists and commercial farmers, under the various simulations carried out in the preceding section. We have omitted the mixed farmers as they were found to not have the resources to play an active role in any of the proposed strategies. However, this does not imply that they are not important. As highlighted earlier, they are presently in a precarious situation whereby any perturbations to their income stream can cause them to drop below the poverty line. We postulate here that removing the forces which are likely to cause these perturbations will go a long way to resolving the poverty issues faced by this group. It is for this reason that we concentrate on the pastoralists and try to find solutions which will remove, or at least substantially reduce, their present state of agitation and resentment towards the mixed farmers. This in turn focuses our analysis on the interaction dynamics between the commercial farmers and the pastoralists, as the results from the previous section attest.

Three possible policy recommendations can be extrapolated from the results shown in Figure 4. The first would be to maintain the present group ranch system but with a number of modifications to make it more efficient and equitable than it presently is. The second option is to implement the full privatisation programme as advocated by many policy-makers. The third option is a policy calling for a hybrid structure containing elements of the group ranch and the fully privatised systems. Each of the policy options mentioned above has its own strengths and weaknesses. We shall now turn our attention to these, and in the process, attempt to identify the appropriate policy proposal with the best chances of success in finding a solution to the present state of conflicts.

\section{Policy option 1}

The first option is to continue with the present group ranch system but with two modifications. The first modification requires the introduction of environmental lease 
contracts whereby the flexible pricing mechanism can be implemented. The strength of this modification is obvious: land degradation activities are minimised. The weaknesses of the flexible pricing mechanism lie in the logistics of drafting, monitoring and implementing the lease contracts. Writing contracts can be a complex and tedious endeavour requiring legal and scientific expertise. The former is required for drafting the contracts in a clear and concise manner which makes it a legally binding document, acceptable to the courts if disputes occur. Scientific knowledge is needed to establish indicators for land degradation and the methods for measuring and monitoring the indicators in a manner which reduces the possibility of disputes and uncertainty. Both types of expertise come with a cost, but a cursory glance at the results from GR-ICLIR show that the opportunity cost of land degradation may far outweigh these institutional transaction costs.

However, even if the best contracts have been drafted, there must be a system, formal or informal, that can implement the contracts in times of dispute and assign penalties to the offending parties. The formal system in many countries takes the form of the judicial system. But in many developing countries, the judicial system has been compromised by special interest groups, and the chances of getting a fair hearing are minimal. If this is the case, an informal system created by the leaders may be needed. The modalities of such a system can be quite complex, but on the other hand, community-based bodies have been in existence in many of these countries, and reviving some of these institutions may be an option if the formal systems have collapsed or have been compromised. In either case, transaction costs are bound to be incurred but compared to the possible gains accruing from the flexible pricing system, these initiatives may be worth the effort.

\section{Policy option 2}

The second modification to the existing group ranch system involves removing the institutional bottlenecks preventing the lessors from leasing all potential agricultural land. This constraint, as shown in simulation GR-NICLIR, is a major limiting factor in increasing the revenues for the pastoralists. The main reason is the breakdown of the traditional institutions which used to govern the use of the commons in the past. Without some form of institutional structure for organising, soliciting and implementing group interests, the task of getting a unanimous decision from all families within the group on land use options becomes complex and time consuming. This results in vast amounts of potential land not being used optimally, whether it be for leasing out to commercial farmers or for their own use. The $10 \%$ of land currently leased out to commercial farmers is, in a majority of cases, leased by an individual or a small group of individuals within the group ranches, without proper authority from the other members of the group (Okoth-Ogendo,1996; Hesse, 1996). In some cases, individuals within the group ranch systems who have had a broader information base on land use options have embarked on commercial farming themselves on group ranch land, but have not distributed the receipts among the other members of the group.

The same situation arises when land under the group ranch system is earmarked for wildlife, and receipts from the wildlife tourist industry are not equally distributed among the ranch members. However, as simulation GR-NICWLIR demonstrates, the present receipts are significantly below the true value of the land, and this is further compounded by the fact that in reality, even this sum is not transferred to the ranch members, but misappropriated by certain members of the group ranch as well as by public bodies (Norton-Griffiths, 1995). In light of these abuses and inefficiencies in the present group ranch system, there has been a growing demand for the ranches to be broken up and private rights to be given to the 
individual families. In fact the Presidential Land Decree of 1997 gave many of the group ranches the option of being privatised if they so desired. But does privatisation resolve the present problems or is it merely a devil in disguise?

As simulation FP-LIR demonstrates, the welfare of the pastoralists does improve significantly and they are pushed well above the poverty line. However, on closer scrutiny, a very different outcome materialises. The pastoralists decide to sell their land. A number of factors influence the decision to sell their land even if this means a decrease in welfare in later periods. First, information asymmetries between the pastoralists and the commercial farmers force many in the former group to adopt a myopic view towards the value of their land. Second, the lack of institutional support has acted as a deterrent to pastoralists, making pastoralism an economically viable activity capable of creating wealth. Third, a relatively low power base combined with a continuing process of fragmentation among the Masai pastoralist society has created an environment conducive to exploitation by powerful insiders as well as outsiders. Although the privatisation policy creates a land market whereby landowners are given the choice of selling or keeping their land, the institutional failures mentioned earlier create far from perfect markets. As North (1995) argues, the pastoralists will make their decisions based on their perception of the environment, which in turn is determined by, among others, the very three factors mentioned above. It would seem that land privatisation at this point in time will actually create an environment whereby the rich, powerful and well informed will take advantage of the incomplete knowledge base - he pastoralists to garner more wealth through the purchase of land. And even if propon of this policy invoke the instrumental rationality assumption as a mechanism to correct these institutional failures, the real problem is that the social cost incurred during the process of information feedback, and the correction of erroneous models is too high to be left to the markets to correct.

\section{Policy option 3}

This now leads us to the third option. Under this option, we propose a hybrid land system comprising elements of both the group ranch and full privatisation land tenure regimes. Under this hybrid institutional structure, the privatisation policy is pursued and all families within the ranches are given titles to specific plots of land. However, under the hybrid system, ownership of land does not automatically imply right of use and exchange. Right of use relates to land use activities while the right of exchange oversees the transfer of land ownership. We advocate a set of rules drawn up collectively by all members of the previous group ranch which explicitly specify these rights. In essence this part retains the group ranch system.

This is in many ways similar to the present system of land boards. One of the functions of the land boards was to oversee the exchange of land, and new owners had to get permission from the land board before they could sell their plot of land. However, the system failed to prevent the sales of land for a number of reasons, chief of which was that the board was headed by a commissioner appointed by the central government, and its members were tribal chiefs and influential members from the district. This led to widespread corruption, including cases in which board members bought land themselves at very low prices and sold these to outsiders later for substantial profits (Rutten, 1992). In order to prevent the same events occurring under the hybrid institutional structure, a more participatory system is advocated whereby all members have a say or vote in all decisions. We shall not go into detail in this paper on the actual design of voting mechanisms, as it is beyond the scope of the study and will be left as a topic for future research. 
The institutional mechanism discussed above looks at the interaction between the members within the group ranch system and sets out the framework for closer cooperation and coordination. However, this still leaves a vacuum for reducing information bias and moving the present system of no instrumental rationality among certain leaders to a platform where full instrumental rationality can be realised by all. In order to achieve this objective, we recommend the formation of an information network whereby information on land use can easily be exchanged and made available to all members. The information network might also serve as a conflict resolution institution through which disputes might be mediated. However, unlike the community s whose membership is composed of families from the previous group ranches, the information network should ideally be comprised of all leaders from the district. The hybrid institutional structure we propose in the above sections is admittedly a complex structure with the potential for high transaction costs. The privatisation component should not pose a big problem as the existing institutional structures should be able to accommodate this process without any additional costs. The community land boards, on the other hand, pose a bigger challenge. First, these institutions need to be legally sanctioned. If this is not possible under the present political system, then informal mechanisms need to be developed to invoke voluntary participation. The information network can play this role in addition to its primary role of information exchange and conflict resolution. By making information available to the individual land owners, the knowledge base of the land owners is increased and, assuming full instrumental rationality is achieved, then the 'right' land exchange and use decisions will be adopted. The critical factor underlying the success of this process is time. If the information network is slow to develop, and the privatisation process has already been initiated, then the time needed for the new land owners to reconceptualise the land economy may not be sufficient for them to make the appropriate decisions, and the results observed in simulation FP-LIRA can be expected to occur.

To end the paper without a discussion on the conservation of wildlife and the tourist industry would constitute a major flaw in our analysis. The international reputation of the wildlife game reserves of the Narok District as a major source of wildlife diversity makes it imperative that we outline the implications of the three policy options discussed above. One outcome that comes clearly across from the results of this study is that wildlife conservation can only be viable if there is some compensation from the global community. Unfortunately, the hybrid system with strengthened information structures will cause the cost of wildlife conservation to increase above the present level. As the pastoralists garner information on alternative land use and value, they will begin to understand the burden they have been bearing in the past for wildlife conservation in the district. With this increasing knowledge and information, the price of wildlife conservation will undoubtedly increase from present levels. If we take the figures provided by our model simulations as an indication, we can assume that tourist receipts by themselves will be insufficient to cover the costs of conservation. Remuneration by the global community will be required to cover the cost differentials. 


\section{Conclusion}

We believe that the results and lessons learned from this study will be useful for analysing similar problems in other developing countries. As mentioned in the introduction, many conflicts witnessed in many developing countries have their roots in land tenure, land use and environmental degradation issues. The rapid introduction of foreign land tenure and market institutions had caused large segments of the population to be marginalised. The few from an elite and privileged class who had an understanding ese new institutions, were able to take advantage of the benefits these institutions had to $\ldots$.... At the other end of the spectrum were those with limited or no knowledge of these new systems, relying instead on the traditional institutions which were left behind, and in many cases, exploited by those with the broader knowledge base. The crux of the matter is that this dichotomy needs to be eradicated or, at least, reduced. In this study, we suggest two institutional mechanisms. The first is a community-based land board which has jurisdiction over land use and exchange. We emphasise here that ownership of land should be privatised and should, under no circumstances, be controlled by the land board as this will be no better than the present group ranch system. The second recommendation is the formation of a network which serves the dual purpose of a forum for conflict resolution and information exchange. In this way, the process of gaining a detailed understanding of the new institutions can be initiated. 


\section{Bibliography}

Bates, R.H. 1995. "Social dilemmas and rational individuals: an assessment of the new institutionalism" in J. Harriss (eds), The New Institutional Economics and Third World Development. Routledge, London: 27-48.

Bullard, R. and H. Waters 1996. "Land tenure, the root of land ownership conflicts in Southern Africa, past, present and future". Roots 96: the Proceedings of the 1996 Rural Practice Research Conference of the Royal Institution of Chartered Surveyors, London: Royal Institution of Chartered Surveyors: 185-196.

Central Bureau of Statistics, 1996. Welfare Monitoring Survey II, 1994, Basic Report, Central Bureau of Statistics, Ministry of Planning and National Development, Nairobi, Kenya.

Central Bureau of Statistics 1998. Economic Survey 1998, Central Bureau of Statistics, Ministry of Planning and National Development, Nairobi, Kenya.

Conroy, C., Rai, A., Singh, N. and Chan, M. 1998. Conflicts affecting participatory forest management: some experiences from Orissa, unpublished manuscript. Natural Resources Institute, Chatham, England.

Dickerman, C. W. 1989. Security of tenure and land registration in Africa: literature review and synthesis. Report of the Land Tenure Center, Madison, USA.

Dietz, T. 1996. Entitlements to Natural Resources. International Books, Utrecht, the Netherlands.

Duraiappah, A.K. 1998. "Poverty and environmental degradation: a review and analysis of the nexus". World Development 29: 2169-2179.

Galaty, J.G. 1980. "The Masai group ranch: politics and development in an African pastoral society" in P.C. Salzman (ed), When Nomads Settle. Processes of Sedentarization as Adaptaion and Response, Praeger, New York: 157-172.

Hesse, C. 1996. Major Issues Facing People in Pastoral Areas, Oxfam, Kenya.

Jaetzold, R. and H. Schmidt, 1982. Farm Management Handbook of Kenya. Natural Conditions and Farm Management Information Vol II, Ministry of Agriculture.

Kanyinga, K. 1998. Struggles of access to land. The 'squatter question' in coastal Kenya. CDR Working Paper: 98.7, Copenhagen, Denmark.

Migot-Adholla, S.E. and J.W. Bruce 1994. "Introduction: are indigenous African systems insecure?" in J.W. Bruce and S.E. Migot-Adholla (eds), Searching for Land Tenure Security in Africa, Dubuque: $1-13$.

MPND (Ministry of Planning and National Development) 1997. NAROK: District Development Plan 1997-2001, Government Publishers, Nairobi, Kenya.

Murga, G.P. 1997. Promised the Earth: Agrarian Reform in the Socio-Economic Agreement, Accord: An International Review of Peace Initiatives. Conciliation Resources, London, England.

North, D. 1990. Institutions, Institutional Change and Economic Performance. Cambridge University Press, Cambridge, UK. 
North, D. 1995. "The new institutional economics and third world development" in J. Harriss (ed), The New Institutional Economics and Third World Development, Routledge, London: 17-26.

Norton-Griffiths, N. 1995. "The Opportunity Costs of Biodiversity Conservation in Kenya". Ecological Economics 12: 125-140.

Norton-Griffiths, N. 1995. "Economic incentives to develop the rangelands of the Serengeti: implications for wildlife conservation" in A.R. Sinclaire and P. Arcese (eds), Serengati II: Dynamics, Management and Conservation of an Ecosystem, University of Chicago Press, Chicago: 588-603.

Ogolla, B.D. 1996. "Land tenure systems and natural resource management" in J. Calestous and J.B. Ojwang (eds), Land We Trust: Environment, Private Property and Constitutional Change. Nairobi and London: 85-116.

Okoth-Ogenda, H.W.O. 1996. Land tenure and natural resource management: the Kenyan experience. Unpublished manuscript presented at the Workshop on Land Tenure Issues in Natural Resource Economics.

Pagiola, S. 1996. "Price policy and returns to soil conservation in Kitui and Machakos, Kenya". Environmental and Natural Resource Economics.

Powelson, J.P and R.Stock 1990. The Peasant Betrayed, The CATO Institute, Washington, D.C.

Rutten, M. 1992. Selling Wealth to Buy Poverty. Verlag Breitenbach Publishers, Saarbrucken and Fort Lauderdale.

Shipton, P. 1988. "The Kenyan land tenure reform: misunderstandings in the public creation of private property" in R.E. Downs and S.P. Reyna (eds.), Land and Society in Contemporary Africa, Hanover, New Hampshire. 


\section{PUBLICATIONS AND ORDERING DETAILS}

The following papers are available for purchase from Earthprint Limited at the address below. Northernbased readers are charged $£ 12.00$ or US\$18 per paper, plus postage and packing. For our Southern readers, hard copies are available free of charge, although larger quantities (more than 6) will incur postal costs. All papers may be downloaded free in PDF format from the CREED website, at www.iied.org/creed. Requests for free papers should be made to Frances Reynolds, Environmental Economics Programme, International Institute for Environment and Development, 3 Endsleigh Street, London WC1H 0DD, or email your requests to frances.Reynolds@iied.org

\section{CREED Working Paper Series.}

No 1. Adjustment policies and the environment: a critical review of the literature. Carlos E.F. Young and Joshua Bishop. July 1995.

No 2. Environmental regulations as trade barriers for developing countries: eco-labelling and the Dutch cut flower industry. Harmen Verbruggen, Onno Kuik \& Martijn Bennis. July 1995.

No 3. Economic incentives for watershed protection: a report on an ongoing study of Arenal, Costa Rica. Bruce Aylward, Jaime Echeverría \& Edward B. Barbier. September 1995.

No 4. Economic policies for sustainable water use in Thailand. Ritu Kumar and Carlos Young. June 1996.

No 5. The informal sector and waste paper recovery in Bombay. Pieter van Beukering, Edwin Schoon and Ajit Mani. June 1996.

No 6. Economic trends in the timber industry of the Brazilian Amazon: evidence from Paragominas. Steven Stone. July 1996.

No 7. Input substitution in the Indian paper industry: a variable cost function approach. K.V. Ramaswamy, R.R. Vaidya, M.J. Bennis and J.G.M. Hoogeveen. July 1996.

No 8. Poverty and environmental degradation: a literature review and analysis. Anantha K. Duraiappah. October 1996.

No 9. Valuation and evaluation of management alternatives for the Pagbilao Mangrove Forest. Ron Janssen and Jose E Padilla. October 1996.

No 10. The economic and environmental impacts of the waste paper trade and recycling in India: a material balance approach. Pieter van Beukering and Anantha K. Duraiappah. November 1996.

No 11. Incentives for eco-efficiency: lessons from an evaluation of policy alternatives; a case study of the steel sector in India. Ritu Kumar, Nick Robins, A.K. Chaturvedi, R. Srinivasan and J. Gupta. December 1996.

No 12. Poverty and environment linkages in mountains and uplands: reflections on the 'poverty trap' thesis. Sanjeev Prakash. February 1997.

No 13. The economic importance of wild resources in the Hadejia-Nguru Wetlands, Nigeria. Derek Eaton and Marie-Thérèse Sarch. May 1997. 
No 14. Economic valuation of mangrove ecosystems: potential and limitations. Frank Spaninks and Pieter van Beukering. July 1997.

No 15. The use of environmental functions to evaluate management strategies for the Pagbilao Mangrove Forest. Alison J. Gilbert and Ron Janssen. August 1997.

No 16 Trends and issues in the plastics cycle in China, with special emphasis on trade and recycling. Pieter van Beukering, Li Yongjiang, Zhao Yumin \& Zhou Xin. December 1997.

No 17. Economic valuation of communal rangelands in Botswana: a case study. Jaap Arntzen. February 1998.

No 18. Environmental product measures: barriers for South-North trade? Harmen Verbruggen, Onno Kuik, Martijn Bennis, Hans Hoogeveen, Roland Mollerus. March 1998.

No 19. The shrimp aquaculture sector in Thailand: a review of economic, environmental and trade issues. Direk Patmasiriwat, Onno Kuik and Sunil Pednekar. October 1998.

No 20. An analysis of private and social discount rates in Costa Rica. Bruce Aylward and Ina Porras. December 1998.

No 21. Institutional arrangements for watershed management: a case study of Arenal, Costa Rica. Bruce Aylward and Alvaro Fernandez Gonzalez. December 1998.

No 22. Farmers' perceptions and sustainable land use in the Atacora, Benin. A. Adegbidi, K. Burger, E. Gandonou and I. Mulder. February 1999.

No 23. Sustainable livestock management in the Kalahari: an Optimal Livestock Rangeland Model (OLRM). Anantha K. Duraiappah and Jeremy S. Perkins. March 1999.

No 24. Analysing urban solid waste in developing countries: a perspective on Bangalore, India. Pieter van Beukering, Madhushree Sekher, Reyer Gerlagh and Vijay Kumar. March 1999.

No 25. Market and policy incentives for livestock production and watershed protection in Arenal, Costa Rica. Bruce Aylward, Jaime Echeverría, Katherine Allen, Ronald Mejías and Ina T. Porras. March 1999.

No 26. Integrated modelling of solid waste in India. Reyer Gerlagh, Pieter van Beukering, Madhu Verma, P.P. Yadav and Preety Pandey. March 1999.

No 27. The plastics sector in China: issues in production, recycling and international trade. Anantha K. Duraiappah, Zhou Xin and Pieter van Beukering. March 1999.

No 28. Farmers' perceptions of soil fertility in Benin Ingrid Mulder. February 2000.

No 29. Automobile pollution control in Brazil. Claudio Ferraz and Ronaldo Seroa da Motta. June 2000.

No 30. Soil fertility: QUEFTS and farmers' perceptions. Ingrid Mulder. July 2000.

No 31. Sustainable shrimp farming: estimations of a survival function . Anantha $K$. Duraiappah, Adis Israngkura and Sombat Sae-Hae. July 2000. 
No 32. Traditional Chinese medicine and species endangerment: an economic research agenda. Konrad von Moltke and Frank Spaninks. August 2000.

No 33. Land tenure, land use, environmental degradation and conflict resolution: a PASIR analysis for the Narok District, Kenya. Anantha K. Duraiappah, Gerrishon Ikiara, Mutsembi Manundu, Wilfred Nyangena and Rueben Sinange. August 2000.

No 34. The environmental effects of tax differentiation by vehicle characteristics: results from Costa Rica. Jaime Echeverría, Nick Johnstone, Ronald Mejías and Ina Porras. September 2000.

No 35. Farm permits and optimal shrimp management in Thailand: an integrated intertemporal and spatial planning model. Anantha Kumar Duraiappah and Adis Israngkura. October 2000.

\section{CREED Final Reports}

The following reports are available from recently completed CREED projects. A charge is levied for all readers.

International Trade and Recycling in Developing Countries: The Case of Waste Paper Trade in India. P. van Beukering and V. Sharma (eds). November 1996. 155 pages.

The importance of international trade in the global economy is expanding, not only for primary products but also for recyclable waste. The main objectives of this study were to determine the economic, social and environmental impacts of international trade of waste paper for recycling purposes in India. The report addresses three main sectors: (i) the world market for waste paper, (ii) the local waste paper market and (iii) the Indian paper industry. It also makes recommendations for policy makers at an international, national and local level: international agreements should distinguish between hazardous and non-hazardous waste; national trade barriers to waste imports should be eliminated; and existing local informal recovery sectors should be favoured over formal Western-style recycling systems.

Mangroves or Fishponds? Valuation and Evaluation of Alternative Uses of a Mangrove Forest in the Philippines. Ron Janssen \& Jose Padilla. September 1997. 258 pages.

One of the major threats to mangroves in the Philippines is the rapidly increasing aquaculture industry. This study includes a review of valuation methodologies and their application to the case study area of the Pagbilao experimental mangrove forest in the Philippines. Valuations of goods and services and environmental functions of the forest are employed to assess alternative management regimes using both cost-benefit analysis as well as a multi-criteria approach. Much depends on the management objectives: conversion to aquaculture is the most economically efficient management option. However, if equity and sustainability objectives are included, commercial forestry is the preferred alternative.

Incentives for Eco-Efficiency. Market Based Instruments for Pollution Prevention: A Case Study of the Steel Sector. Ritu Kumar, Nick Robins, A.K. Chaturvedi, R. Srinivasan and J. Gupta. December 1997. 96 pages.

Mounting pressures on industry to reduce pollution, to remain globally competitive and to meet the requirements of international standards, require fundamental changes in government 
policy and corporate approaches to environmental management. This report presents the results of an international study assessing the potential for market-based instruments for pollution prevention in the steel sector in India. It recommends a set of policy measures to reduce discharge levels in the most cost effective manner, to induce firms to adopt cleaner technologies and to encourage firms to economise on energy and water resources. In this regard, the importance of achieving coherence with existing policies, building trust among key stakeholders and gradually phasing in market-based instruments is emphasised.

Economic Incentives for Watershed Protection: A Case Study of Lake Arenal, Costa Rica. Bruce Aylward, Jaime Echeverria, Alvaro Fernandez Gonzalez, Ina Porras, Katherine Allen, Ronald Mejias. February 1998. 323 pages.

Conventional wisdom holds that cutting down tropical forests for livestock production is not only bad business but bad for the environment. In particular, it is thought that conversion of natural forest to pasture leads to a rise in the sedimentation of waterways and resevoirs, increased risk of flooding and loss of dry season water supply. In the case of Lake Arenal, Costa Rica, this conventional view is stood on its head by research showing that ranching, dairy farming and associated downstream hydrological effects represent important positive values to the Costa Rican economy, values that significantly outweigh expected returns from reforestation

Plastics Recycling in China. An International Life Cycle Approach. Edited by Pieter van Beukering. April 1999. 148 pages.

\section{Orders:}

Earthprint Limited

Orders Department

P.O. Box 119

Stevenage

Hertfordshire SG1 4TP

England

Fax: 441438748844

Email: orders@earthprint.co.uk

\section{Enquiries:}

Tel: 441438748111

Fax: 441438748844

Email: enquire@earthprint.co.uk

\section{Shipping Charges:}

Please add payment for postage and packing at the following rates:

\begin{tabular}{|l|l|}
\hline UK & US\$5.00 for the first item plus US\$2.50 for each additional item \\
\hline Europe & US\$6.00 for the first item plus US\$3.00 for each additional item \\
\hline Rest of World & US\$10.00 for the first item plus US\$5.00 for each additional item \\
\hline
\end{tabular}




\section{How to Pay:}

Credit card You can pay by VISA, Mastercard, Access or Eurocard. Please include the cardholder address and expiry date.

Cheque

Cheques should be in US dollars, drawn against a US bank and made payable to Earthprint Limited. (UK customers can pay in the Sterling equivalent.- conversion rate US\$1.50 $=£ 1.00$

Bank Transfers Bank transfers should be made to:

The Bank of New York

51 West 51 st Street

New York

NY 10019

USA

Account number: 6301545051 